\title{
Variation Of Productivity, Wages And Profitability With Location
}

\author{
Edward M. Miller*
}

Many comparisons of different areas of the country have been made with regard to such variables as wage rates or rates of growth of employment. However, little attention has been paid to such key variables as productivity or profitability. Yet, low wages could be (and are) offset by low productivity.

Perhaps even more surprising is the absence of research on differences in profitability. In theory, industrialists pick locations on the basis of anticipated profitability, and the areas with the highest profits would be the fastest growing. In spite of the theoretical importance of profitability, regional scientists have made little effort to determine how it varies with location. This paper will argue that gross profit margins can be measured from existing data, and that there are significant regional differences in profitability. Finally, comparisons of wages will be made and new indices of wage rates will be computed with industry mix controlled for.

\section{METHODOLOGY FOR CALCULATING PRODUCTIVITY INDICES}

The basic data were taken from the 1972 Census of Manufacturers. The measure of productivity used was value added divided by the number of production worker manhours. Value added is superior to value of shipments as a measure of output because it controls for differing degrees of vertical integration. The number of production worker manhours was taken as the measure of labor input since it incorporated the number of hours worked, and true labor input (direct labor plus overhead) is likely to be proportional to it. Some regions are much more likely than others to have overhead labor (accounting, research, etc.) located at the factories (where it would be included in establishment level total employment). It was believed that to include such functions for some establishments (some of which may have been for establishments in other states) but not others would be less accurate than excluding them for all establishments.

These calculations were made for all regions, divisions, states, and SMSAs for which there were data. Naturally, not all industries are represented in all areas. More importantly, the Census Bureau is prohibited by

*Tsanoff Professor of Public Affairs, Jesse H. Jones Graduate School of Administration, Rice University, P.O. Box 1892, Houston, Texas 77251 
law from disclosing information about any particular company. To avoid one firm's being able to subtract its data from the total and thus to determine another firm's submission, the Census Bureau will release data only if the industry in question has at least three companies in a particular state or metropolitan area. This disclosure rule proves a severe limitation, especially for the industries characterized by large plants, such as steel, automobiles, or tobacco.

There are, of course, numerous potential problems with using value added per production worker as a measure of labor productivity. One is that the output is measured in dollars and not in physical quantities. Since the comparisons are made between areas for a single year, the dollar values are in the same year's prices, avoiding the very difficult problem of finding suitable price deflators at the four-digit level. The possibility that prices differ significantly with location remains. If good regional price indices existed, it would be desirable to deflate the output by price indices. However, the lack of suitable price indices prevents the use of this procedure.

Fortunately regional differences in the price of manufactured goods tend to be small. Most manufactured goods are sold in national markets, and firms in different locations must price at approximately the same level in order to compete. Thus, the use of dollar values is a reasonable approximation to physical output. The ability to make comparisons using dollar values of value added was a major reason for studying the manufacturing sector. The same procedure would not work for most other sectors which sell only in local markets.

If gross profit is defined (as it is here) as value added minus payroll, there is an identity

$$
\text { Value Added = Payroll + gross profit. }
$$

Dividing through by manhours one has

$$
\frac{\text { Value Added }}{\text { Manhours }}=\frac{\text { Payroll }}{\text { Manhours }}+\frac{\text { Gross Profit }}{\text { Manhours }}
$$

This reduces to

\section{Labor Productivity $=$ Average Hourly Earnings + Gross Profit per Manhour}

If one believes that gross profits per manhour are fixed and output prices are set as a markup on local costs, productivity is not an independent variable. Consider the house construction industry. Suppose there are two communities, one union and one non-union. They are separated by large enough distance that houses in the two communities do not compete. One would expect that in each community houses would sell for approximately the costs of construction, or the price of the materials plus the required 
labor. The prices of houses in the high-wage union area will be much higher than those in the low-wage union area. One could not use value of house put in place per manhour as a measure of labor productivity because $\$ 10,000$ worth of house would be quite different in the two locations, representing much less house in the union city. In particular, one could not argue that just because union labor had a higher value of output per manhour it was more productive. (This explains Allen's [1979] conclusions that unionized construction workers are more productive.) Similar problems would arise if value added was used as a surrogate for physical output in services, retail trade, or wholesale trade. This problem could even arise for a few manufacturing industries that sell in local market areas, but in most manufacturing industries competition from firms in other areas prevents prices being merely a reflection of local wages and costs.

Gross profit in manufacturing is not an exogenous variable that is constant at all locations but is a residue left after the payroll and cost of materials have been deducted from value of output. For manufacturing, prices are not set as a markup on local costs but are the result of national factors, such as national demand and supply or price leadership by national firms. This makes gross profit variable, reflecting the differences between national product prices and local costs. Thus gross profit can and does vary between locations. Locational theory suggests that firms will seek locations where this gross profit is large.

Where productivity is unusually high, there are a number of possible beneficiaries. One possibility is the workers. The evidence (see below) of a correlation between wages and productivity suggests they get at least some of the benefits of high productivity. In some cases land owners benefit. (They are much more likely to receive the rents for industries such as mining, agriculture, or even retail trade where output per worker is likely to be much higher on one tract of land than on another.) Since taxes vary with location, state and local governments probably receive some part of the difference. Finally, as noted above, owners of capital probably receive much of the difference in the form of differences in profit rates.

With the data available, quite a few variables cannot be controlled for. One is the degree of market power. Factories in one location may show higher profits and productivity than those in another area not because they really have higher productivity, but because they had enough market power to raise prices substantially above long-run marginal costs. If there is no control for industry mix (or only a control at the two digit level), this can be a serious problem. Since certain industries have substantial market power, comparing value added per worker for a community whose leading industries have market power to that for another community with competitive industries can be very misleading. Fortunately, most such differences are controlled for by making comparisons across four-digit industries. For instance, Rochester, New York, has a value added per man hour that is among the highest in the nation, being over twice the national average. This is probably due to the presence of Kodak, Xerox, and Bausch and Lomb. These firms have substantial market power and high 
markups over the cost of production. Their gross profits include not only a normal return on invested capital but also a return to a heavy investment in research and development and well-recognized brand names.

There is one other factor that minimizes the importance of differences in market power. The Census Bureau will publish data on a particular industry only if there are at least three firms in the industry in that state or metropolitan area. Thus the industries for which there are data are typically the competitive industries, minimizing the problems of noncompetitive pricing.

Since one firm's market power typically raises prices of all firms in the industry, controlling for industry mix helps control for differences in concentration among communities. A similar argument would apply for such variables as short-run supply and demand considerations and capital intensity, for which data are not available. Failure to control for such variables is much more serious for studies of all manufacturing or at the two-digit level than it is when industry mix is controlled for at the four digit level.

\section{TABLE 1}

Productivity, Wage, and Profit Margin Indices for States and Regions

\begin{tabular}{lrrr}
\hline & $\begin{array}{c}\text { Produc- } \\
\text { tivity }\end{array}$ & Wages & $\begin{array}{r}\text { Profit } \\
\text { Margin }\end{array}$ \\
\hline Northeast & 101.9 & 103.8 & 97.1 \\
New England & 96.8 & 96.6 & 101.9 \\
Maine & 88.5 & 91.8 & 97.2 \\
New Hampshire & 74.6 & 87.6 & 80.7 \\
Vermont & 82.1 & 90.4 & 89.5 \\
Massachusetts & 104.5 & 99.0 & 109.7 \\
Rhode Island & 97.0 & 93.2 & 109.7 \\
Connecticut & 93.3 & 96.2 & 93.4 \\
Middle Atlantic & 104.4 & 106.7 & 95.8 \\
New York & 116.9 & 107.1 & 96.5 \\
New Jersey & 94.3 & 104.3 & 95.9 \\
Pennsylvania & 94.4 & 101.6 & 97.7 \\
North Central & 102.4 & 110.2 & 97.2 \\
East North Central & 101.7 & 111.8 & 95.4 \\
Ohio & 104.0 & 106.5 & 99.4 \\
Indiana & 98.3 & 102.2 & 90.7 \\
Illinois & 106.9 & 108.5 & 99.6 \\
Michigan & 100.4 & 111.3 & 91.4 \\
Wisconsin & 104.3 & 103.6 & 103.1 \\
West North Central & 97.2 & 98.6 & 100.6 \\
Minnesota & 107.6 & 108.2 & 108.6 \\
Iowa & 106.3 & 112.0 & 94.1 \\
Missouri & 85.5 & 94.2 & 96.6 \\
\hline
\end{tabular}


TABLE 1 (Continued)

Productivity, Wage, and Profit Margin Indices

for States and Regions

\begin{tabular}{|c|c|c|c|}
\hline & $\begin{array}{l}\text { Produc- } \\
\text { tivity }\end{array}$ & Wages & $\begin{array}{c}\text { Profit } \\
\text { Margin }\end{array}$ \\
\hline North Dakota & 74.0 & 79.7 & 99.2 \\
\hline South Dakota & 76.6 & 74.3 & 103.3 \\
\hline Nebraska & 94.0 & 95.3 & 78.5 \\
\hline Kansas & 84.2 & 83.8 & 94.1 \\
\hline South & 91.6 & 86.8 & 107.0 \\
\hline South Atlantic & 96.4 & 90.5 & 105.1 \\
\hline Delaware & 73.7 & 85.1 & 88.3 \\
\hline Maryland & 97.6 & 93.6 & 99.6 \\
\hline District of Columbia & 156.8 & 109.3 & 91.3 \\
\hline Virginia & 93.7 & 89.8 & 106.3 \\
\hline West Virginia & 83.1 & 92.4 & 114.3 \\
\hline North Carolina & 96.5 & 92.7 & 101.7 \\
\hline South Carolina & 93.8 & 95.6 & 93.8 \\
\hline Georgia & 95.4 & 91.1 & 103.8 \\
\hline Florida & 95.1 & 88.9 & 103.3 \\
\hline \multicolumn{4}{|l|}{ East South } \\
\hline Central & 89.3 & 87.9 & 102.9 \\
\hline Kentucky & 85.8 & 94.3 & 100.1 \\
\hline Tennessee & 88.1 & 86.1 & 110.2 \\
\hline Alabama & 94.8 & 92.1 & 115.0 \\
\hline Mississippi & 77.6 & 81.4 & 101.1 \\
\hline West South Central & 96.8 & 88.5 & 103.4 \\
\hline Arkansas & 82.5 & 79.7 & 110.4 \\
\hline Louisiana & 116.5 & 93.4 & 107.4 \\
\hline Oklahoma & 93.0 & 87.0 & 104.3 \\
\hline Texas & 111.6 & 89.9 & 116.6 \\
\hline West & 111.3 & 110.9 & 105.3 \\
\hline Mountain & 94.9 & 99.0 & 106.3 \\
\hline Montana & 88.3 & 91.4 & 120.6 \\
\hline Idaho & 104.2 & 125.5 & 92.3 \\
\hline Wyoming & 75.1 & 88.2 & 114.7 \\
\hline Colorado & 93.4 & 101.4 & 93.8 \\
\hline New Mexico & 90.0 & 80.0 & 112.6 \\
\hline Arizona & 133.9 & 102.9 & 133.1 \\
\hline Utah & 120.9 & 89.9 & 138.0 \\
\hline Nevada & 107.3 & 97.2 & 119.4 \\
\hline Pacific & 110.8 & 115.7 & 99.9 \\
\hline Washington & 113.0 & 120.4 & 100.2 \\
\hline Oregon & 123.6 & 126.9 & 101.4 \\
\hline California & 106.1 & 107.4 & 98.2 \\
\hline Alaska & 116.9 & 126.1 & 165.5 \\
\hline
\end{tabular}




\section{SUMMARIZING THE DATA}

These detailed, industry-by-industry calculations occupied several thick printouts, far too much data to present here. It is obviously necessary to calculate summary measures of productivity. One might like to calculate weighted indices of productivity where each industry had the same weight in each area. This could not be done because there are virtually no industries that are represented everywhere. The industries either do not exist (such as ship building in Colorado) or disclosure regulations prevent the required data from being revealed. Since indices with national weights could not be calculated, a series of indices was calculated using local weights.

The question asked was what would be the value added if each local industry with data had the average productivity of the rest of the nation for that industry. The actual 1972 value added was divided by this hypothetical value added to give the observed value added as a percentage of the hypothetical value added, or the productivity index (See Table 1). The results are also shown on the attached maps.

This index compares local productivity with productivity of the rest of the nation using local weights. This procedure thus gives high weight to the industries which are important to an area (and for which the government can publish data). In using these numbers, this should be kept in mind. A statement that Oregon industries (such as sawmills) have high productivity, as do New York industries (such as apparel), may have few implications for the efficiency of a new automobile plant in either location.

\section{REGIONAL DIFFERENCES IN PRODUCTIVITY}

There are regional differences in productivity. Productivity tends to be highest in the West and lowest in the South. In the South, 1972 productivity was running $8 \%$ below the national average while in the West it was $11 \%$ above the national average. The low productivity for the South was especially surprising since it had been expected that with more modern factories productivity would be higher there. Productivity in the traditional Industrial Belt of the Northeast and the North Central states was slightly above the national average (by $2 \%$ ).

There were a few interesting patterns within the regions. Although productivity for the Northeast was slightly above the national average, the patterns were quite different for its two divisions. New England was about $3 \%$ below the national average while the Middle Atlantic states were 4\% above the national average. In the North Central Region, the West North Central states have a productivity below the national average. Finally, the high productivity in the West is primarily in the Pacific Coast states, with the Mountain states actually about $5 \%$ below the national average.

In considering locations for new plants, it should be realized that many variables influence productivity and that productivity from existing plants is a poor indicator of many of these variables. Frequently, different plants in the same industry produce different types or qualities of output. In 


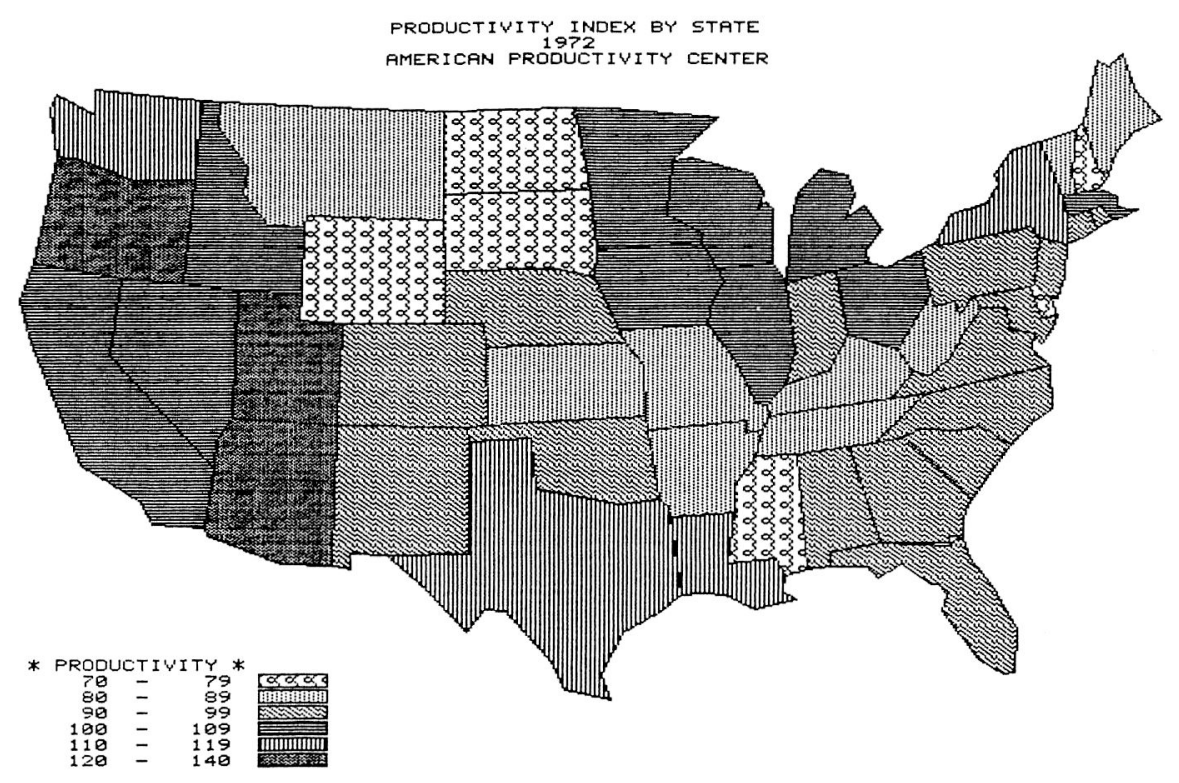

Figure 1

addition, existing plants are often obsolete or burdened with old work rules. An area that has low productivity in existing plants might suffer no productivity disadvantage in new plants.

\section{WAGES}

A similar procedure was followed in calculating the wage level. The average wage for each of the 450 manufacturing industries was calculated by dividing the total production-worker payroll by the number of production-worker manhours to give production-worker wages in dollars per hour. A weighted index was constructed using local productionworker manhours as weights. The total wage that would be paid if each industry in the area paid the national average wage was calculated. The actual wage bill was expressed as a percentage of this potential wage, giving local wages as a percentage of the national level.

The resulting index is an indicator of whether an industrialist seeking a location should expect to pay above average or below average wages for his industry. It is less useful for the potential worker seeking a job since he may earn much more in a machinery factory paying low wages for the machinery industry than in a textile factory paying high wages for the textile industry. The results are given in Table 1 and are shown on the Wages map.

The pattern of wages observed was very similar to that found in other studies. Wages are lowest in the South and highest in the West. It is interesting to see that this pattern is not due merely to differences in 
industrial mix but also holds even when the mix is controlled for at a very high level of detail (four-digit).

Wage levels and productivity tend to move together. Differences in productivity tend to offset part of the advantage of low wages. For instance, wages in the South are about $8 \%$ lower than in the rest of the nation, but the output per manhour is typically $4 \%$ lower, leaving the advantage in output per dollar of wages less than would have been deduced from the differences in wages alone. The West has wages that run about $11 \%$ higher than the national average, but it also has output per manhour of that is about $11 \%$ higher than the national average, with the result that the West does not have the disadvantage in labor costs its above-average wage rates would suggest.

This strong relationship between levels of productivity and wages was also observed in the divisional data and in the data for the states. There are enough states to permit a statistical test of a wage productivity relationship. Thus a regression for the states of the productivity ratio on the wage ratio was run. The result was (standard error in parenthesis):

$$
\begin{gathered}
\text { Wage ratio }=.384+\underset{(.084) \quad .664 \text { Productivity Ratio }}{\quad \mathrm{R}^{2}=.56}
\end{gathered}
$$

The relationship was statistically significant. States with low wages also have low productivity. Those interested in industrial location may want to consider the possibility of lower productivity offsetting part of the gains from lower wages in low wage areas.

There are of course a number of mechanisms that could produce the observed correlation between wages and productivity. High wages could cause firms to substitute capital for labor, resulting in high labor productivity in high wage areas. In fact some researchers have attempted to estimate the elasticity of substitution between capital and labor using two-digit data on the assumption that the major mechanism causing differences between states in labor productivity are differences in capital intensity induced by differences in wages (Moroney [1972], Ferguson [1963], Griliches $[1967])$. Such an analysis depends on the assumption (among others) that there is a single technology employed in each two-digit industry. In actuality, each two-digit industry is composed of a number of separate industries employing different technologies and having different skill requirements, capital intensities, and degree of market power. The mix of these industries between different states differs quite widely. This author believes that attempts to work at the two-digit level without standardization for industry mix is likely to lead to serious error. The work reported on here shows that standardization for differences in industrial mix is possible.

Wages may be based partially on ability to pay, resulting in high productivity firms paying high wages. High labor quality could lead to both high wages and high productivity. There are a number of hypotheses that are 


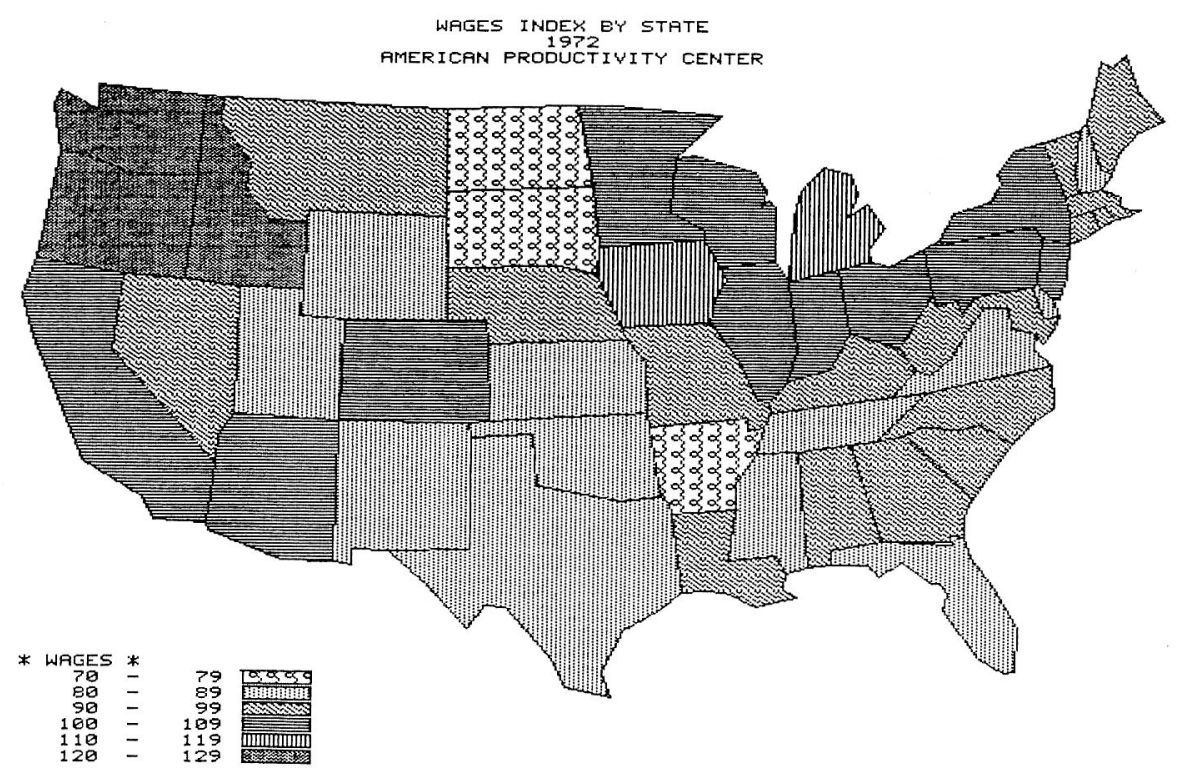

Figure 2

consistent with data. Thus these results are presented in the hope of inspiring further work by others that may cast light on the causal relationships.

\section{PROFITABILITY}

Using the Census of Manufactures data, it is possible to calculate a gross profit margin by region. This is done by subtracting the total payroll from the value added and then dividing the remainder by the value of shipments. Since value added is essentially value of production minus raw materials, parts, packaging, and energy, the remainder after subtracting labor costs is a gross margin, roughly equivalent to contribution to overhead. It includes not only profit as normally defined but also interest payments, fringe benefits, purchased services (including repairs and insurance), and services typically provided off-site such as accounting or research. Since many of these expenses would occur wherever the plant was located, excluding them in the comparisons of different locations is reasonable. These gross profit margins are included in the tables and are shown in the map of gross profit margins. They are the first published measures of profitability by region. It is hoped that they (possibly updated) will be used in future studies of the determinants of industrial location and rates of growth.

Some systematic differences in profitability by region were found. Gross profit margins appeared to be higher in the "Sunbelt" than in the "Snowbelt." The Northeast and the North Central both had profits margins that were below the national average by about $3 \%$. In contrast, the margins for 


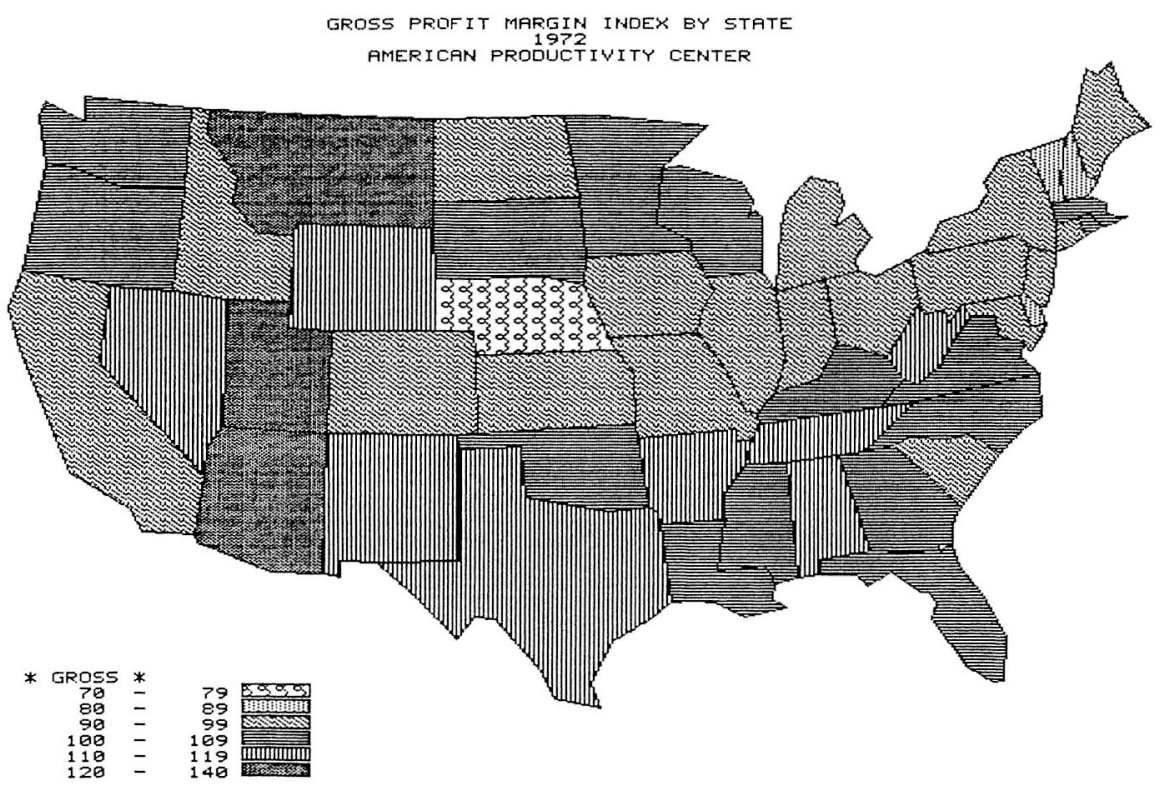

Figure 3

the West average over $7 \%$ above the national average. The highest profit margins appear to be in the South, where they were running $7 \%$ above the national average.

\section{THE RELATIONSHIP BETWEEN REGIONAL PRODUCTIVITY, WAGES, AND PROFIT MARGINS}

A series of tests of the relationship between the wage rates, profit margins, and productivity were run using the regional ratios. The basic data were the productivity, wage, and profit margin ratios for the 450 four-digit industries and for the four Census Regions (Northeast, North Central, South, and West). While not all industries were represented in all regions, there were 1788 observations, which are enough to provide a high degree of statistical significance. The ratios had been standardized by dividing the regional value by the national averages, thus making data for different industries comparable.

A regression of the wage ratio on the productivity ratio gave:

$$
\begin{gathered}
\text { Wage Ratio }=67.8+.312 \text { Productivity Ratio } \\
(.011) \quad \mathrm{R}^{2}=.288
\end{gathered}
$$


The estimated coefficient is sufficiently in excess of the standard error that there is virtually no chance of the relationship being due solely to chance. Thus when a particular industry in a region has above average productivity, its wages are likely to be above average. Some of the possible causal mechanisms for this relationship have been discussed above. Each increase in productivity of $1 \%$ appears to be associated with an increase in wages of about $.3 \%$.

Having shown that wages appear to be closely related to productivity, the next question is whether there is a similar relationship between profitability and productivity. A regression of the profitability ratio on the productivity ratio gave:

$$
\begin{gathered}
\text { Profitability Ratio }=91.4+\underset{(.036)}{.086 \text { Productivity Ratio }} \\
\mathrm{R}^{2}=.0037
\end{gathered}
$$

Thus, profitability tends to increase with productivity and the relationship is statistically significant. If a region has above average productivity in a particular industry it is likely to have above average profitability. The effect of productivity on profitability is probably attentuated by the tendency for high productivity regions to also have high wages.

An additional question is whether, given the relationship between profitability and productivity, there is any tendency for the low wage region to be more profitable. Needless to say, the fact that productivity and wages are correlated does not prevent them from being included in the same equation, although it increases the standard errors. A multiple regression equation shows:

$$
\begin{aligned}
& \text { Profitability Ratio }= \\
& \begin{array}{r}
99.5+.124 \text { Productivity Ratio }-.120 \text { Wage Ratio } \\
(.0435) \\
(.075) \\
\mathrm{R}^{2}=451 \%
\end{array}
\end{aligned}
$$

Thus, if there is any independent effect of wages on profitability, it is more likely to be negative than positive. However, the coefficient is small enough so that there is a $10.7 \%$ chance that it is actually positive rather than negative. This relationship between wages and profitability is surprisingly weak given the popular belief that being in a high wage area puts one at a fatal disadvantage. With wages controlled for, the effect of productivity on profitability is increased. Thus, there is a tendency for the industries within a region which are above the national average for their industry in productivity also to have above average wages and profitabilities. 


\section{RESULTS FOR METROPOLITAN AREAS}

Similar calculations were performed using the metropolitan area statistics. They are shown in Table 2 for the fifty most important manufacturing centers.

A set of comparisons was also made for each industry between the average productivities, wages, and profitabilities, in the metropolitan areas and the country as a whole. Weighted averages were then calculated (as was done above) using weights based on the urban area (or more specifically, the number of production worker manhours reported for specific

\section{TABLE 2}

Productivity, Wages, and Profitability by City

\begin{tabular}{|c|c|c|c|c|c|c|}
\hline City, State & $\begin{array}{l}\text { Number of } \\
\text { Employees }\end{array}$ & $\begin{array}{l}\text { Value } \\
\text { Added }\end{array}$ & $\begin{array}{c}\text { Produc- } \\
\text { tivity } \\
\text { Ratio }\end{array}$ & $\begin{array}{l}\text { Wage } \\
\text { Ratio }\end{array}$ & $\begin{array}{l}\text { Profit- } \\
\text { ability } \\
\text { Ratio }\end{array}$ & $\begin{array}{l}\text { No. of } \\
\text { Industries } \\
\text { Included in } \\
\text { Average }\end{array}$ \\
\hline $\begin{array}{l}\text { Chicago, IL } \\
\text { Los Angeles- }\end{array}$ & 909.6 & $17,573.8$ & 0.974 & 1.074 & 0.924 & 50 \\
\hline Long Beach, CA & 778.9 & $15,234.9$ & 1.015 & 1.042 & 0.985 & 166 \\
\hline New York, NY-NJ & 949.2 & $15,120.8$ & 1.228 & 1.087 & 0.950 & 189 \\
\hline Detroit, MI & 551.6 & $11,694.3$ & 1.048 & 1.142 & 0.886 & 70 \\
\hline Philadelphia, PA-NJ & 495.7 & $9,189.9$ & 0.969 & 1.043 & 0.942 & 185 \\
\hline Newark, NJ & 271.8 & $5,608.6$ & 0.986 & 1.030 & 0.937 & 87 \\
\hline Cleveland, $\mathrm{OH}$ & 268.9 & $5,220.9$ & 1.044 & 1.070 & 0.957 & 78 \\
\hline St. Louis, MO-IL & 250.2 & $5,161.1$ & 0.936 & 1.013 & 0.993 & 89 \\
\hline Boston, MA & 266.5 & $4,918.9$ & 1.083 & 1.037 & 0.975 & 83 \\
\hline Rochester, NY & 142.2 & $4,390.6$ & 0.927 & 1.060 & 0.993 & 19 \\
\hline Houston, TX & 162.7 & $4,179.4$ & 1.210 & 1.017 & 1.048 & 57 \\
\hline $\begin{array}{l}\text { Pittsburgh, PA } \\
\text { Dallas- }\end{array}$ & 262.8 & $4,163.9$ & 0.886 & 1.013 & 0.730 & 53 \\
\hline $\begin{array}{l}\text { Fort Worth, TX } \\
\text { San Francisco- }\end{array}$ & 230.0 & $4,075.7$ & 0.954 & 0.882 & 0.993 & 78 \\
\hline Oakland, CA & 184.8 & $3,807.9$ & 1.212 & 1.222 & 1.019 & 83 \\
\hline $\begin{array}{l}\text { Minneapolis-St. Paul, } \\
\text { MN-WI }\end{array}$ & 199.0 & $3,734.8$ & 1.051 & 1.070 & 0.970 & 73 \\
\hline Milwaukee, WI & 200.0 & $3,700.0$ & 0.996 & 1.108 & 0.926 & 49 \\
\hline Cincinnati, OH-KY-IN & 157.6 & $3,561.2$ & 0.978 & 1.008 & 1.038 & 47 \\
\hline Baltimore, MD & 180.1 & $3,476.2$ & 1.009 & 0.941 & 0.958 & 18 \\
\hline Buffalo, NY & 151.7 & $3,146.3$ & 0.955 & 1.111 & 0.861 & 32 \\
\hline Louisville, KY-IN & 113.4 & $3,022.8$ & 1.127 & 1.038 & 1.101 & 15 \\
\hline Kansas City, MO-KS & 118.8 & $2,902.4$ & 1.074 & 1.036 & 1.039 & 41 \\
\hline San Jose, CA & 134.4 & $2,873.1$ & 1.252 & 1.182 & 1.093 & 23 \\
\hline $\begin{array}{l}\text { Anaheim-Santa Ana- } \\
\text { Garden Grove, CA }\end{array}$ & 131.0 & $2,734.4$ & 1.053 & 1.041 & 0.994 & 46 \\
\hline
\end{tabular}


TABLE 2 (Continued)

Productivity, Wages, and Profitability by City

\begin{tabular}{|c|c|c|c|c|c|c|}
\hline City, State & $\begin{array}{l}\text { Number of } \\
\text { Employees }\end{array}$ & $\begin{array}{l}\text { Value } \\
\text { Added }\end{array}$ & $\begin{array}{l}\text { Produc- } \\
\text { tivity } \\
\text { Ratio }\end{array}$ & $\begin{array}{l}\text { Wage } \\
\text { Ratio }\end{array}$ & $\begin{array}{l}\text { Profit- } \\
\text { ability } \\
\text { Ratio }\end{array}$ & $\begin{array}{l}\text { No. of } \\
\text { Industries } \\
\text { Included in } \\
\text { Average }\end{array}$ \\
\hline $\begin{array}{l}\text { Greensboro-Winston- } \\
\text { Salem-High Point, } \\
\text { NC }\end{array}$ & 138.0 & $2,593.4$ & 0.934 & 0.998 & 0.907 & 25 \\
\hline Indianapolis, IN & 122.5 & $2,525.3$ & 0.947 & 0.970 & 0.936 & 22 \\
\hline Atlanta, GA & 132.4 & $2,472.3$ & 1.056 & 0.943 & 0.983 & 38 \\
\hline Seattle-Everett, WA & 108.6 & $2,234.7$ & 1.299 & 1.291 & 1.096 & 20 \\
\hline Dayton, $\mathrm{OH}$ & 118.8 & $2,152.9$ & 0.859 & 0.999 & 0.861 & 17 \\
\hline Gary-Hammond-East & & & & & & \\
\hline Chicago, IN & 99.4 & $2,159.0$ & 0.899 & 0.994 & 0.779 & 6 \\
\hline $\begin{array}{l}\text { Columbus, OH } \\
\text { Providence-Warwick, }\end{array}$ & 102.4 & $1,989.2$ & 1.007 & 0.981 & 0.984 & 22 \\
\hline Pawtucket-RI-MA & 131.9 & $1,959.9$ & 0.998 & 0.905 & 1.154 & 19 \\
\hline Jersey City, NJ & 95.3 & $1,899.2$ & 0.942 & 1.081 & 0.799 & 28 \\
\hline Toledo, OH-MI & 91.2 & $1,878.9$ & 1.195 & 0.995 & 1.166 & 16 \\
\hline Denver-Boulder, CO & 95.5 & $1,849.8$ & 0.956 & 1.000 & 0.930 & 21 \\
\hline $\begin{array}{l}\text { Allentown-Bethlehem- } \\
\text { Easton, PA-NJ }\end{array}$ & 110.4 & $1,805.6$ & 0.805 & 1.054 & 0.872 & 21 \\
\hline $\begin{array}{l}\text { Youngstown-Warren, } \\
\mathrm{OH}\end{array}$ & 86.6 & $1,749.5$ & 0.970 & 1.002 & 0.950 & 10 \\
\hline Akron, $\mathrm{OH}$ & 94.4 & $1,686.2$ & 1.021 & 1.078 & 0.839 & 11 \\
\hline Portland, OR-WA & 86.4 & $1,596.9$ & 1.160 & 1.148 & 0.991 & 41 \\
\hline Grand Rapids, MI & 74.9 & $1,515.4$ & 1.050 & 0.992 & 1.102 & 24 \\
\hline Hartford, CT & 86.4 & $1,395.5$ & 0.966 & 0.933 & 0.955 & 15 \\
\hline Phoenix, AZ & 71.9 & $1,370.0$ & 0.931 & 1.158 & 0.963 & 7 \\
\hline Memphis, IN-AR-MS & 64.2 & $1,352.4$ & 0.850 & 0.874 & 0.961 & 25 \\
\hline Albany-Schenectady- & & & & & & \\
\hline Troy, NY & 66.9 & $1,322.0$ & 0.927 & 1.001 & 1.069 & 12 \\
\hline Miami, FL & 86.0 & $1,219.0$ & 0.859 & 0.893 & 1.023 & 40 \\
\hline Syracuse, NY & 60.5 & $1,205.3$ & 1.002 & 0.972 & 1.079 & 16 \\
\hline $\begin{array}{l}\text { Paterson-Clifton- } \\
\text { Passaic, NJ }\end{array}$ & 75.5 & $1,179.4$ & 0.811 & 1.058 & 0.966 & 32 \\
\hline Springfield-Chicopee- & & & & & & \\
\hline Holyoke, MA & 62.1 & $1,157.7$ & 0.984 & 0.916 & 1.083 & 17 \\
\hline Canton, OH & 57.6 & $1,151.6$ & 0.985 & 1.076 & 0.926 & 9 \\
\hline Bridgeport, CT & 63.7 & $1,137.6$ & 1.058 & 1.049 & 1.120 & 83 \\
\hline Birmingham, AL & 68.9 & $1,123.8$ & 0.956 & 0.920 & 1.004 & 16 \\
\hline \multicolumn{7}{|c|}{ Standard Consolidated Areas } \\
\hline \multicolumn{7}{|l|}{ New York, NY } \\
\hline New Jersey & $1,622.0$ & $28,352.9$ & 1.099 & 1.072 & 0.948 & 293 \\
\hline \multicolumn{7}{|l|}{ Chicago, IL } \\
\hline NW Indiana & $1,009.0$ & $19,732.8$ & 1.007 & 1.063 & 0.931 & 231 \\
\hline
\end{tabular}


TABLE 3

Productivity, Wage, and Profit Ratios

For Metropolitan United States

\begin{tabular}{|c|c|c|c|c|}
\hline $\begin{array}{l}\text { Two Digit } \\
\text { SIC Code }\end{array}$ & $\begin{array}{l}\text { Industry } \\
\text { Name }\end{array}$ & $\begin{array}{l}\text { Average } \\
\text { Productivity }\end{array}$ & $\begin{array}{l}\text { Average } \\
\text { Wages }\end{array}$ & $\begin{array}{c}\text { Average } \\
\text { Profit } \\
\text { Margin }\end{array}$ \\
\hline 20 & Food & 1.056 & 1.082 & 0.959 \\
\hline 21 & Tobacco & 0.595 & 1.021 & 0.468 \\
\hline 22 & Textiles & 0.991 & 1.032 & 0.921 \\
\hline 23 & Apparel & 1.142 & 1.045 & 0.921 \\
\hline 24 & Lumber & 1.214 & 1.153 & 0.971 \\
\hline 25 & Furniture & 1.016 & 1.024 & 0.942 \\
\hline 26 & Paper & 0.921 & 0.983 & 0.921 \\
\hline 27 & Printing & 1.113 & 1.082 & 0.987 \\
\hline 28 & Chemicals & 0.957 & 1.017 & 0.939 \\
\hline 29 & Petroleum & 1.025 & 1.070 & 1.060 \\
\hline 30 & Rubber \& Plastics & 0.979 & 1.011 & 0.844 \\
\hline 31 & Leather & 0.950 & 1.019 & 0.880 \\
\hline 32 & Stone, Clay \& Glass & 0.956 & 1.038 & 0.866 \\
\hline 33 & Primary metals & 0.984 & 1.015 & 0.947 \\
\hline 34 & Fabricated metals & 1.049 & 1.042 & 1.031 \\
\hline 35 & $\begin{array}{l}\text { Machinery, non- } \\
\text { electrical }\end{array}$ & 0.999 & 1.016 & 0.943 \\
\hline 36 & Electrical machinery & 0.965 & 0.984 & 0.930 \\
\hline \multirow[t]{2}{*}{37} & Transportation & & & \\
\hline & Equipment & 1.018 & 1.000 & 1.066 \\
\hline 38 & Instruments & 1.002 & 0.980 & 0.979 \\
\hline \multirow[t]{2}{*}{39} & $\begin{array}{l}\text { Miscellaneous } \\
\text { manufacturing }\end{array}$ & 1.011 & 1.009 & 0.927 \\
\hline & $\begin{array}{l}\text { All Manufacturing } \\
\text { Average }\end{array}$ & 1.025 & 1.034 & 0.947 \\
\hline
\end{tabular}

metropolitan areas for indices of productivity and wages, and the value of shipments in specific metropolitan areas for the index of profitability).

For each industry, the sum of the value added was divided by the sum of the production worker manhours to give a measure of the productivity in the metropolitan areas for which there were data. (Of course, there were no published data for many cities.) This figure was divided by the corresponding national productivity to give the metropolitan productivity as a percent of the national. An unweighted average of these figures showed productivity in metropolitan areas to be $2.5 \%$ above the national average. This provides direct evidence on productivity in cities, supplementing the previous evidence which had inadequate control for industry mix (Carlino, Sveiklauskas, and Yezer and Goldfarb).

A similar procedure was applied to wages. They were found to be $3.5 \%$ above the national averages. Since this figure exceeds the $2.5 \%$ average metropolitan advantage in productivity, labor costs appear to be higher in metropolitan areas. 
Calculations were made for profits. Profits in metropolitan areas were found to average $5.2 \%$ below the national average. This result is not surprising in view of the higher labor costs.

Table 3 shows the averages of the four digit values (unweighted) of the metropolitan productivity, wage, and profitability ratios for each two digit industry grouping.

A major handicap in doing studies of metropolitan versus nonmetropolitan areas is the absence of any totals for metropolitan areas. The researcher has to compute his own totals by adding up the published data for the individual metropolitan areas. Since data are published only if there are three or more companies, the metropolitan areas with only one or two companies in an industry are excluded. For most industries, a significant proportion of total industry capacity is in those cities with less than three companies. Since a total for all metropolitan areas cannot be computed, it is impossible to derive figures for the non-metropolitan areas by subtraction. The most that can be done is to compare the metropolitan areas for which there are data with the rest of the country.

The percentage differences reported here between metropolitan averages and the national averages are small. This is to be expected since most manufacturing takes place in metropolitan areas, and the metropolitan areas are included in the national averages. One would prefer to make comparisons between metropolitan and non-metropolitan areas, but as noted above data for non-metropolitan areas cannot be obtained. This is a deficiency the Census Bureau could easily correct.

\section{CONCLUSIONS}

There are significant differences between regions, states, and metropolitan areas in productivity, wages, and profitability. Frequently, an area that has an advantage in wage rates finds part of this advantage offset by lower productivity. There are interesting correlations between many of the variables. Like many research projects, this one raises more questions than it answers. Having shown the types of interesting data that can be constructed, it remains to combine data of this type with data from other sources to construct a complete model that would explain the way the world actually works.

\section{REFERENCES}

Allen, Steven G. "Unionized Construction Workers are More Productive," Center to Protect Worker's Rights (November 1979).

Bensen, Stanley M. "Education and Productivity in U.S. Manufacturing: Some Cross-Sectional Evidence," Journal of Political Economy (May-June, 1968).

Carlino, Gerald A. "Increasing Returns to Scale in Metropolitan Manufacturing," Journal of Regional Science, 19, 3 (1979): 363-374.

Ferguson, C. E. "Cross-Section Production Functions and the Elasticity of Substitution in American Manufacturing Industry," Review of Economics and Statistics, 45 (August 1963): 305-13.

Griliches, Zvi. "Production Functions in Manufacturing: Some Preliminary Results" in the Theory and Empirical
Analysis of Production, ed. M. Brown (New York: National Bureau of Economic Research, 1967) pp. 275322.

Moroney, J. R. The Structure of Production in Manufacturing, (Chapel Hill: University of North Carolina Press, 1972).

Sveikauskas, L. "The Productivity of Cities," Quarterly Journal of Economics, 89 (1975): 393-413.

Yezer, A. M. J. and Goldfarb, R. S., "An Indirect Test of Efficient City Size," Journal of Urban Economics, 5 (1978): 46-65.

U.S. Bureau of the Census, Census of Manufactures, 1972 (Washington, DC: U.S. Government Printing Office, 1975). 